\title{
MEANINGFUL INFORMATION FOR DOMESTIC ECONOMIES IN THE LIGHT OF GLOBALIZATION - WILL ADDITIONAL MACROECONOMIC INDICATORS AND DIFFERENT PRESENTATIONS SHED LIGHT?
}

\author{
Silke Stapel-Weber \\ Paul Konijn \\ John Verrinder \\ Henk Nijmeijer \\ Working Paper 24859 \\ http://www.nber.org/papers/w24859
NATIONAL BUREAU OF ECONOMIC RESEARCH
1050 Massachusetts Avenue
Cambridge, MA 02138
July 2018

The views expressed in this paper are those of the authors, not necessarily those of Eurostat, the National Bureau of Economic Research, or the European Commission. The authors would like to thank Eurostat colleagues, and notably August Götzfried, Karin Isaksson, Merja Rantala and Veijo Ritola for their helpful comments.

NBER working papers are circulated for discussion and comment purposes. They have not been peer-reviewed or been subject to the review by the NBER Board of Directors that accompanies official NBER publications.

(C) 2018 by Silke Stapel-Weber, Paul Konijn, John Verrinder, and Henk Nijmeijer. All rights reserved. Short sections of text, not to exceed two paragraphs, may be quoted without explicit permission provided that full credit, including ()$^{\text {notice, }}$ is given to the source. 
Meaningful Information for Domestic Economies in the Light of Globalization - Will Additional Macroeconomic Indicators and Different Presentations Shed Light?

Silke Stapel-Weber, Paul Konijn, John Verrinder, and Henk Nijmeijer

NBER Working Paper No. 24859

July 2018

JEL No. E01

\begin{abstract}
Globalisation presents significant statistical challenges, particularly for small and open economies in terms of measuring macroeconomic level and growth indicators and communicating the results in a meaningful way. In the aftermath of the so-called "Irish case", Eurostat with its partners in the European Statistical System is looking into how, within the existing accounting frameworks, additional indicators and presentations of the accounts that allow users to follow domestic and global developments could be conceived. The work takes account of recommendations which have been developed by a high level group in Ireland for improving insight into the Irish economy2. However it goes beyond that, as any new indicator or breakdown, particularly in a European context, should be comparable across countries and not be seen as a GDP or GNI "a la carte" for each country to choose from under specific circumstances.

The paper presents the findings of the respective European work streams to date in terms of methodology, indicators, building new statistical infrastructural elements and new cooperation models between statistical compilers. It invites a critical review of the suggestions put forward.

Silke Stapel-Weber

Eurostat

Silke.stapel@ec.europa.eu

Paul Konijn

Eurostat

Paulus.Konijn@ec.europa.eu

John Verrinder

Eurostat

John.Verrinder@ec.europa.eu

Henk Nijmeijer

Eurostat

henk.nijmeijer@ec.europa.eu
\end{abstract}




\title{
CRIW 2018
}

\section{Meaningful Information for Domestic Economies in the Light of Globalization - Will Additional Macroeconomic Indicators and Different Presentations Shed Light?}

\author{
Silke Stapel-Weber, Paul Konijn, John Verrinder, Henk Nijmeijer (Eurostat) ${ }^{1}$
}

\section{Executive summary}

Globalisation presents significant statistical challenges, particularly for small and open economies in terms of measuring macroeconomic level and growth indicators and communicating the results in a meaningful way. In the aftermath of the so-called "Irish case", Eurostat with its partners in the European Statistical System is looking into how, within the existing accounting frameworks, additional indicators and presentations of the accounts that allow users to follow domestic and global developments could be conceived. The work takes account of recommendations which have been developed by a high level group in Ireland for improving insight into the Irish economy ${ }^{2}$. However it goes beyond that, as any new indicator or breakdown, particularly in a European context, should be comparable across countries and not be seen as a GDP or GNI "a la carte" for each country to choose from under specific circumstances.

The paper presents the findings of the respective European work streams to date in terms of methodology, indicators, building new statistical infrastructural elements and new cooperation models between statistical compilers. It invites a critical review of the suggestions put forward.

\section{Introduction}

Globalisation is a historic process of increasing interaction between national economies on a world-wide scale. While not new, interconnectedness has accelerated in recent years as it is closely related to activities by Multi-National Enterprises (MNEs). Fragmented production processes span the world, exploiting comparative production advantages and tax competition between nations. This is also helped by the fact that increasingly a main component of many (particularly high tech) products is intellectual property. These intangible assets of an MNE, however, are extremely mobile and often huge.

In methodological terms, in the most recent releases of the international standards for National Accounts and BOP (2008 SNA, ESA 2010, BPM6), globalisation phenomena such as "goods sent abroad for processing" and "merchanting", "special purpose entities" or "other captive institutions" have been given more attention and subsequently more detailed guidance has been developed. Various tools have already been developed by statisticians and initiatives have been taken to go "beyond GDP".

\footnotetext{
${ }^{1}$ The views expressed in this paper are those of the authors, not necessarily those of Eurostat. The authors would like to thank Eurostat colleagues, and notably August Götzfried, Karin Isaksson, Merja Rantala and Veijo Ritola for their helpful comments.

${ }^{2}$ See the presentation of John Fitzgerald at this Conference for further details, and also a summary in section 4 of this paper.
} 
We have, however, to admit that we are only at the very beginning of getting a grip on properly measuring globalisation in a systematic cross-country way in practice. Which parts of the production activities of MNEs are actually 'taking place' on the domestic territory of any given country? Or, in other words, how can we distinguish between movements in GDP or its components which are relevant for the domestic economy and those which are driven by the worldwide activities of multinational companies?

Efforts to single out globalisation activities and present them alongside purely domestic developments are very challenging, given that they require statisticians to isolate in balance sheets and flow accounts those positions and flows relating to the re-routing of revenues and profits. This may require infra-MNE information and raises sensitive questions concerning enhanced cross border cooperation amongst statistical authorities.

Nevertheless, the price for not addressing them would be increasing irrelevance of our statistical products and persistent/growing bias and asymmetries between countries. Users of statistics need to understand clearly how (and how much) globalisation phenomena impact on those statistics, and which statistics are useful for which analytical purpose. This is particularly important for users, who focus on one or a few aggregates for their needs, and where statistics are used for direct administrative purposes ${ }^{3}$.

\section{Current and future policy developments impacting on macroeconomic data}

The impacts of globalisation can be seen in longer term trends driven by economic fundamentals ${ }^{4}$ but also - and particularly for smaller countries - in discrete MNE business model restructuring events, often triggered by policy developments that change the "rules of the game".

Over recent years, as a response to popular concerns about the impacts of globalisation (and apparent impunity with which MNEs can "offshore"), we have seen an acceleration in coordinated policy developments which are designed to further regulate MNEs and, at least, improve the transparency of their financial affairs.

The best known of these initiatives at international level is the "Base Erosion and Profit Sharing" (BEPS) project led by the OECD. The recommendations of the project, agreed and published in 2015, have led to implementation of new requirements for MNE financial reporting across many jurisdictions worldwide, and in particular for "country-by-country" reporting requirements by $2020^{5}$. This improves the transparency of MNE operations, which would have previously been brought together only in high level consolidated company accounts and tax returns.

In Europe, one of the major impacts of the initiative has been the end of certain tax structures which were widely used by non-European (and often US-owned) MNEs, such as the "Double Irish" and the "Dutch sandwich", to be replaced by a focus on the tax treatment of intellectual property ("Patent boxes", accelerated depreciation) and the need for MNEs to demonstrate

\footnotetext{
${ }^{3}$ For example in Europe in setting contributions to the EU budget (GNI) or for fiscal policy (government deficit and debt / GDP).

${ }^{4}$ For example, see the article "The retreat of the global company" in the Economist magazine, January $28^{\text {th }}$ 2017.

${ }^{5}$ For more details see http://www.oecd.org/tax/beps.
} 
"substance" in an economy in order to benefit from local tax rules. This has already been observed to have impacts on some MNEs' business structures, with movements of intellectual property and increased specification of decision-making functions.

It is also evident in Europe that other policy initiatives are closely accompanying the taxation agenda. For example, successive state aid cases (for example for Apple in Ireland, Amazon in Luxembourg, Starbucks in the Netherlands) have shown the willingness of the European Commission to challenge the selective tax treatment of some MNEs.

Looking forward, one can see that recently agreed reforms, or those under discussion, could bring further triggers for changes to MNE business models.

There is a widespread anticipation that the latest round of corporate tax reforms in the US will provide an incentive for US-owned MNEs to repatriate (at least some of) their accumulated profits so far held abroad ${ }^{6}$, and to relocate some of their physical operations to the US (or at least favour the US in future developments).

There are also ongoing developments in Europe. In 2017 the European Commission released a communication on the taxation of the digital economy ${ }^{7}$. This underlined the principle that taxation should take place 'where profits and value are generated', and has been interpreted as a push to tax the operations of digital enterprises based on the location of the source of revenues that they generate (whether from consumers or businesses) ${ }^{8}$.

Broader political developments may also bring pressures for MNE restructuring. Depending on the eventual way in which "Brexit" is implemented, one might also expect a significant reorganisation of MNEs with substantial UK operations. This might range from the establishment of (small or even token) branches in "EU27" countries, through to the physical relocation of operations and staff.

Thus, aside from the longer term trends in the impacts globalisation arising from developments in economic fundamentals, we have seen a rise in MNE restructuring and can anticipate that this may even accelerate in future. Given the potential impacts on macroeconomic statistics across countries, and the adverse reaction of users to 'surprises' in data, this presents a major challenge to official statisticians. Addressing that challenge will need coordinated development of the "statistical infrastructure" (broadly defined, see section 3 below) and improved communication to users, including extended data availability (see sections 4 and 5 below).

\footnotetext{
${ }^{6}$ Exactly how this might be done is still unclear, though one might expect the use of (one off) dividends or flows relating to intellectual property (royalties). One of the tax reform's major, but less reported, features is that MNEs would be taxed on use of intellectual property wherever it is located (thereby removing some of the incentive to locate intellectual property 'offshore' or in low-tax jurisdictions), though the reform does not provide a low-cost way to relocate existing intellectual property to the US.

${ }^{7}$ See https://ec.europa.eu/taxation_customs/business/company-tax/fair-taxation-digital-economy_en

${ }^{8}$ It is interesting to see that Facebook is somehow anticipating these developments by moving to a model of declaring its advertising revenues in the countries where they are generated (though no doubt to be offset by attributed costs from intellectual property and other 'central' costs).
} 


\section{Improving EU statistical infrastructure to capture globalisation}

To ensure high quality, consistent and complete micro- and macroeconomic statistics it will be necessary to upgrade our statistical infrastructure, in particular as regards the data production on MNE groups (MNEs). Countries' statistical offices will have to cooperate much more closely than is the case today to make sure that the recording of flows and stocks belonging to MNEs are consistent across countries. Whereas "balancing the national accounts" used to mean integrating data sources on the three approaches to GDP (whether or not in a supply/use framework) at national level, in the future the balancing should also take place at the international level. Asymmetries in balance of payments data could, for example, be indicators of inconsistent treatment of MNEs.

At national level, a trend is observed in several EU countries for the balancing of data sources to be undertaken "upstream", i.e. at the national data collection point. Several countries have established, and others are in the process of establishing, so-called "Large cases units" (LCUs) to ensure a consistent treatment of MNEs in national statistics. Depending on the business model chosen, these units collect centrally all data from the largest MNEs in a country, coordinate national data collections and/or ensure their consistency, before being processed for the various statistical outputs. They often provide a single point of contact between the statistical office and the MNE.

While these LCUs are very important tools for the NSIs, they still focus on consistency at national level only. As said above, to tackle globalisation challenges, NSIs will also have to work more closely together than in the past.

A lot of groundwork for this is already being undertaken in Europe. For example, the EuroGroups Register (EGR) is the statistical register of the EU on MNEs. For 2016, the EGR covers around 110000 multinational enterprise groups active in the EU (i.e. having at least one legal unit in the EU) ${ }^{9}$. The EGR requires a close cooperation between the EU countries and Eurostat; the exchange of data is regulated with legal acts. ${ }^{10}$ EU statistical institutes and Eurostat are continuously working on the EGR to improve its quality. This has been achieved from year to year with the best coverage so far for the 2016 reference year.

The EGR contains information on the following units and characteristics:

- legal units: identification, demographic, control and ownership characteristics;

- enterprises: identification and demographic characteristics, main activity code (NACE), number of persons employed, turnover, institutional sector;

- enterprise groups: identification characteristics, the structure of the group, the group head, the country of global decision centre, main activity code (NACE), consolidated employment and turnover of the group.

Hence, the EGR compiles all above units within multi-national enterprise groups (including the ownership structures and relationships). It is important to underline: the MNE structures are obtained by collecting and combining national business register information from all countries in which the MNE has a legal unit.

\footnotetext{
9 For some experimental statistics based on the EGR, see http://ec.europa.eu/eurostat/statisticsexplained/index.php?title $=$ Structure_of_multinational_enterprise_groups in the EU

${ }^{10}$ E.g. Regulation $177 / 2008$
} 
This information is a crucial input for the next stage: European profiling of MNEs. Profiling is defined as "a method to analyse the legal, operational and accounting structure of an enterprise group at national and world level, in order to establish the statistical units within that group, their links, and the most efficient structures for the collection of statistical data". Thus, the focus is shifted from legal units in the business register to statistical units from which data can be collected. The statistical units can be groups of legal units (forming an enterprise). Profiling is an activity that is carried out by business statisticians, often within the LCUs mentioned above, at national level. European profiling brings the countries concerned by one enterprise group together with the aim to agree on the structure, the perimeter and the global decision centre of the group and to describe its activities - across countries - in an economically meaningful way. Profiling of the largest groups is done in consultation with the MNE itself and is a crucial step in getting an up-to-date understanding of MNE structures and ensuring their consistent recording across countries. So far, about 300 MNEs (most of them with European headquarters) have been profiled at European level. The benefits from profiling are integrated into the national statistical business registers and thus improve their quality. There is also the intention to integrate the profiling results into the EGR in a more automated way in the future.

Learning from the 2016 "Irish case", and in parallel to the above projects, Eurostat and the NSIs have also set-up an "Early Warning System", which aims at the early detection of important restructuring of MNEs; as described above, these restructuring events often impact macroeconomic or business statistics. The early reception of such information allows discussion and agreement on the statistical treatment of these events before they have to be included in published statistics, and thereby ensure consistency, and, if needed, a timely and coordinated communication to users.

The above listed developments will require a change of approach from NSIs: it will no longer suffice to focus on what happens within national borders. For the quality and relevance of national statistics, cooperation and exchange of information at international level will be essential to correctly reflect the activities of MNEs.

\section{Presenting and/or extending national accounts data ${ }^{11}$ in times of globalisation?}

\section{Alternative existing indicators}

GDP is a measure of (net) output of an economy. The income side of GDP reflects the income generated in production processes resident in the economy, which is not the same as the income accruing to its citizens. National accountants know very well that there are a multitude of alternative indicators produced within the national accounts that are better measures of income, such as:

- Gross National Income (GNI): a measure of the gross primary income earned by residents of a country. The difference with GDP consists of the net flows of primary income with the rest of the world. Hence, it is less sensitive to globalisation as any profits earned by foreign companies are not included. However, it is still a gross

\footnotetext{
${ }^{11}$ Of course one can also consider alternative presentation for other macroeconomic indicators, notably Balance of Payments. This paper does not do so in this and following sections, concentrating on national accounts, however an important issue to consider is if alternative indicators across different macroeconomic datasets should also be consistent with each other.
} 
measure, i.e. including consumption of fixed capital, and thus not a measure of income as finally received by residents.

- Net National Income (NNI): derived from GNI by taking out consumption of fixed capital. It is thereby a step closer to a pure income measure for the economy as a whole.

- Gross or Net National Disposable Income (NDI): derived from GNI or NNI, respectively, by adjusting for net flows of current transfers with the rest of the world. This is finally what is available to the economy for consumption or saving.

- Disposable income however is more commonly used for households only. Gross or net household disposable income is the share of NDI that accrues to households. Adjusting for social transfers in kind finally gives Adjusted (gross or net) Disposable Income of Households.

All of these indicators are income measures and thus potentially useful as indicators for increased or decreased material welfare of residents of the economy.

Another indicator that is closely related to Adjusted Disposable Income of Households is Actual Individual Consumption, which aggregates the final consumption expenditure of households and NPISHs with the final individual consumption expenditure of general government. This is conceptually a very comparable measure across countries. It is, on average in the EU, about $70 \%$ of GDP and is not affected by globalisation as it excludes GFCF and net exports. This indicator may deserve more attention in national publications than it currently gets.

Figure 1 shows a comparison of GDP and AIC per capita (in PPP terms). It shows they are mostly highly correlated except for two countries strongly affected by globalisation: Luxembourg and Ireland. The high GDP per capita in Luxembourg is partly due to the country's large share of cross-border workers in total employment. While contributing to GDP, these workers are not taken into consideration as part of the resident population which is used to calculate GDP per capita. Luxembourg still has the EU's most affluent residents as measured by AIC per capita. Eurostat has since long caveated the GDP level of Luxembourg in its news releases; in that sense, it is not "news" that GDP can be distorted by globalisation (albeit globalisation on a more regional scale).

Since 2016, Eurostat has also provided footnotes on the level of Irish GDP for years after 2015 in these cross-country comparisons, describing it as being "substantially affected by the relocation from outside the EU to Ireland of balance sheets of large multi-national enterprises". Indeed, where Ireland's GDP per capita stands at more than $80 \%$ above EU average, its AIC per capita is just below the corresponding EU average. It is clear that AIC gives a more realistic picture of the material living standards of Irish residents than GDP.

For some years now, Eurostat's news releases with cross-country comparisons in PPP terms no longer use GDP per capita in its headline but AIC per capita ${ }^{12}$.

12 See e.g. http://ec.europa.eu/eurostat/documents/2995521/8536114/2-14122017-BP-EN.pdf/0c8f87ee42e8-4474-b7c6-724515917ea5. It should be noted that media attention has waned somewhat since Eurostat dropped GDP from the headline. 
Figure 1: Volume of GDP and AIC per capita in PPS, EU28=100, 2015

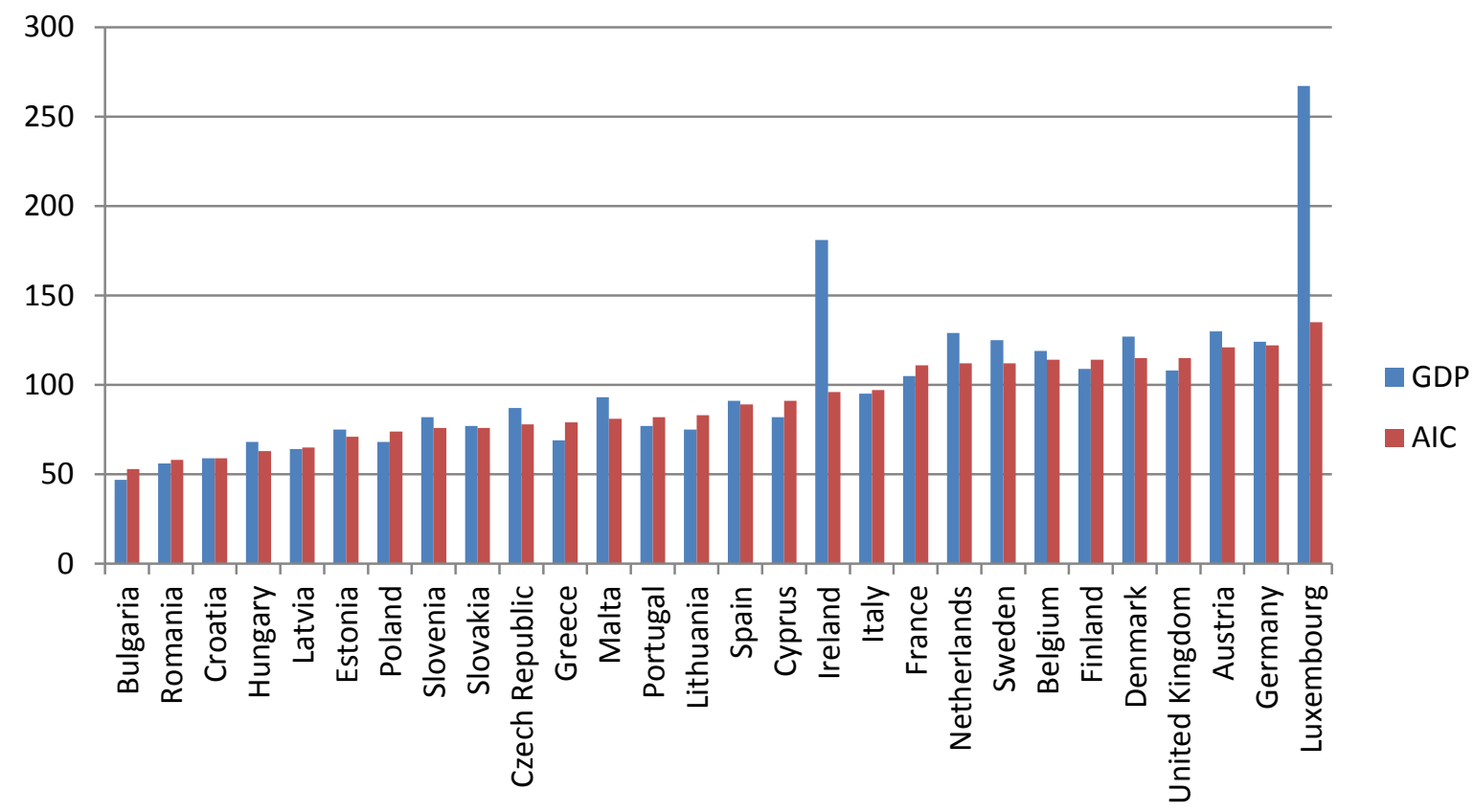

Follow the money

With respect to a common underlying question - what actually arrives at the domestic population in terms of improved material conditions as result of globalisation - it is also interesting to have a look at the tax income of the government. Fig. 2 below shows by means of example the income from corporate tax in Ireland from 2007 to 2016 . There is a noticible increase between 2014 and 2015, which coincides with the relocation of the balance sheets of a small number of large MNEs to Ireland in 2015. If this will contribute to better material welfare of the domestic Irish population depends on what use this increased tax income will be made of now and in the years to come. One can, however, not say that the increased GNI in Ireland is a pure statistical fantasy and nothing happens in the "real economy". Follow the money....

Fig. 2: Taxes on the income or profits of corporations, mln, euro

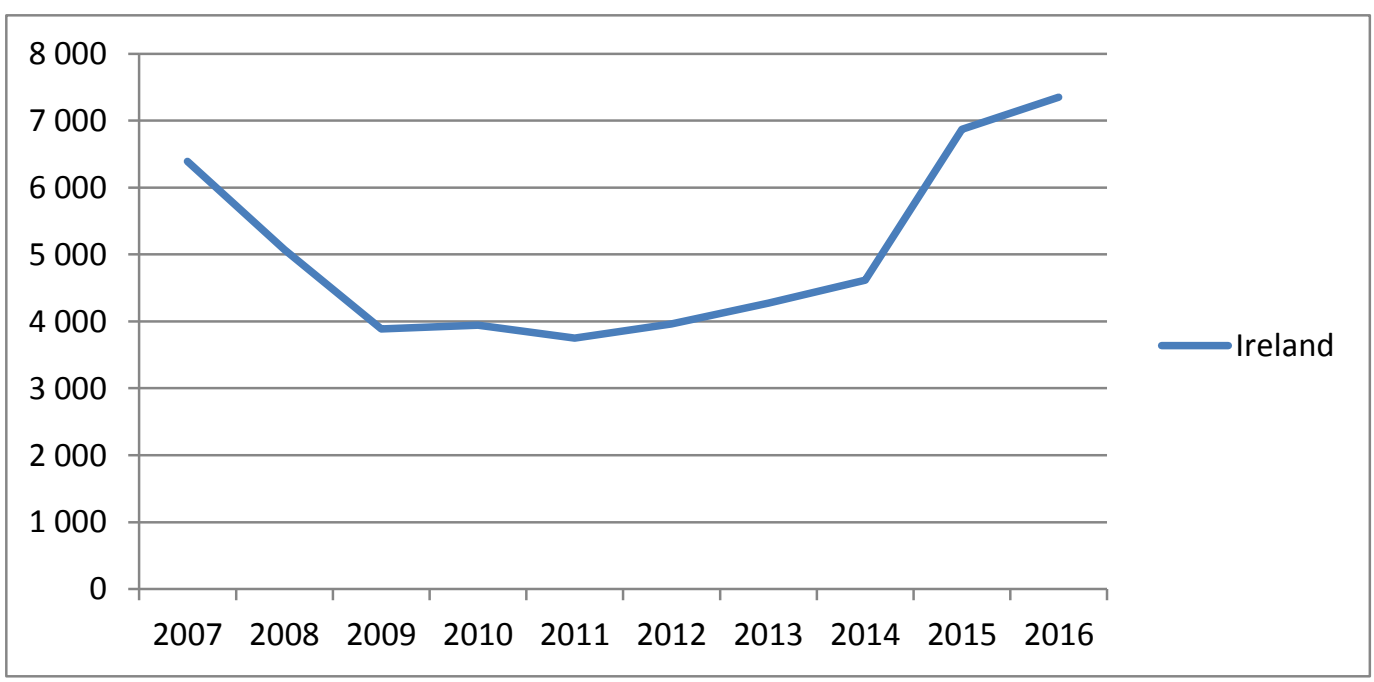




\section{But what about growth rates?}

The most high profile national accounts indicator is not the level of GDP but the volume growth of GDP. What alternatives exist for that?

The national and disposable income measures mentioned above do not have a natural volume component. Deflation of income is about finding an appropriate measure of price change that reflects changes in the purchasing power of that income. OECD publishes income measures at constant prices using the implicit deflator for domestic demand (total consumption plus total capital formation) ${ }^{13}$.

Eurostat publishes - for EU members and European aggregates - the real growth of adjusted GDI of households per capita, together with real AIC per capita, using the price index of AIC as a deflator for both.

For communication purposes, the international statistical community could agree on an (existing) measure of income growth to promote instead of, or in addition to, GDP growth. This would also include agreement on deflators to use to measure real income.

Nevertheless, GDP is also seen by users as a measure of "economic power". For that purpose, it is hard to replace.

\section{Additional breakdowns}

Additional detailed data on globalisation will help users to better understand economic developments. In the wake of the large revision to Ireland's GDP in 2016, the Economic Statistics Review Group (ESRG) produced recommendations to the Irish CSO on how to meet user needs for greater insight into Irish economic activity. Even if written for the specific Irish situation, their report ${ }^{14}$ provides a useful starting point for a discussion on additional data and breakdowns.

The main recommendation is to split the accounts for the non-financial sector in a part related to the largest MNEs and the rest. One could also consider breakdowns according to other dimensions, such as foreign control (see below) or size, or of other parts of the accounts, such as the supply and use tables. Each dimension will tell a different story, but essentially provides information on the phenomenon of globalisation as such.

A breakdown of sector S11 Non-financial enterprises by ownership is already foreseen in ESA 2010, although Eurostat collects no data for this from the EU Member States.

Work in this direction is also being undertaken in the context of Extended Supply and Use Tables that are being promoted by OECD as part of the Trade in Value Added project. Several EU Member States are already working on this.

Another recommendation from the ESRG is to provide users with information on the impact of globalisation on the economic data, for example to provide the transition from international trade in goods data to national accounts and balance of payments data on

\footnotetext{
${ }^{13}$ OECD also includes measures in PPP terms using the PPPs for GDP.

${ }^{14}$ http://www.cso.ie/en/media/csoie/newsevents/documents/reportoftheeconomicstatisticsreviewgroup/Econ omic_Statistics_Review_\%28ESRG\%29_Report_Dec_2016.pdf
} 
exports and imports, i.e. by showing explicitly the adjustments made for goods for processing and merchanting (at product level).

One could also imagine data that show how much production abroad is allocated to the domestic economy following the principle of economic ownership. Such a "building blocks" approach was proposed in the article of Silke Stapel-Weber and John Verrinder in EURONA $2 / 2016^{15}$.

\section{New indicators?}

The above-mentioned report of the ESRG also recommended producing and disseminating an adjusted level indicator. To meet the analytical needs identified by national users, the ESRG recommended the development of a modified version of GNI (named GNI*) with the effects of certain globalisation activities excluded.

For many purposes it is important to generate reliable measures of the aggregate size of the economy. The ESRG states that it has long been recognised that GDP is an inadequate indicator for Ireland, given the size of measured factor income accruing to the foreign owners of multinational enterprises (MNEs) operating in Ireland. For this reason, GNI has been widely employed as an alternative indicator, since GNI strips out net international factor income flows.

Already prior to the 2016 'events' it was suggested by users that even GNI is no longer a sufficiently useful alternative indicator. The impacts of entities moving their global headquarters into or out of Ireland have always caused difficulties for users of Irish statistics.

The ESRG proposes to compile an adjusted measure of GNI, named GNI*, excluding the retained earnings of companies that are predominantly owned by foreign portfolio investors. By extension, an equally adjusted measure of the current account should be published.

In addition, due to the strong increase of the foreign-owned domestic capital stock, due to the relocation of foreign-owned IPP assets into Ireland, an adjustment of the capital stock and thus of the associated consumption of fixed capital is proposed. The ESRG recommends that GNI* should exclude the depreciation of foreign-owned domestic capital.

There are pros and cons to developing alternative, special-purpose, indicators like the proposed GNI*. Clearly, at a national level, they may serve an important purpose or satisfy certain users. But it is not clear whether the same indicator would be relevant for other countries too, or even be useful in one country over time (when different forms of restructuring may have different impacts). It would also be confusing to users (and a step back in time) if different countries would start using different, incomparable, headline indicators for their economies.

\footnotetext{
${ }^{15} \mathrm{http} / /$ ec.europa.eu/eurostat/cros/system/files/euronaissue2-2016-art2.pdf
} 


\section{Some experimental data}

In this section, we present experimental data, which demonstrate that it is possible to describe effects of globalisation on the national economies within the existing indicator framework, by combining available information.

What remains is to develop these experimental indicators into parts of future standard releases on NA and work with users to enable them to make use of the additional information provided.

Combining FATS and NA - value added in the EU generated by foreign controlled enterprises

As a first example, figure 2 combines data from the inward Foreign Affiliates statistics (FATS) and national accounts ${ }^{16}$ to show the share of total economy value added created by foreign controlled enterprises in 2014, broken down into control by intra-EU and by extra-EU units.

Figure 2: Share of total economy value added created by foreign controlled enterprises, by region of foreign control, 2014

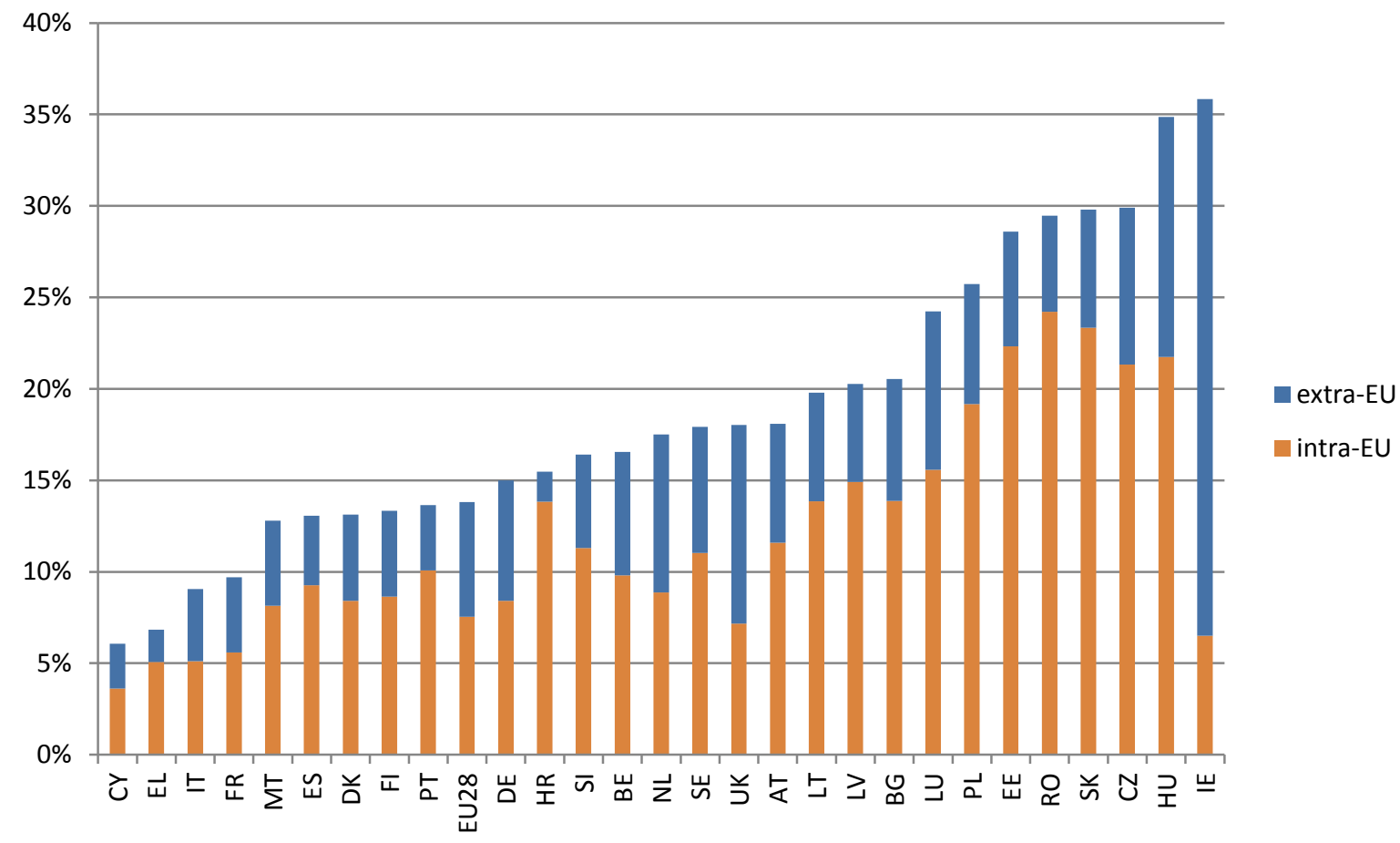

Not surprisingly, Ireland is the country with the highest share of foreign controlled value added created in the EU $(36 \%)^{17}$. More than $80 \%$ of this value added is produced by enterprises with mother companies outside the EU. Slightly more surprising is the high position of five central and eastern European countries (Hungary (35\%), Czech Republic

\footnotetext{
${ }^{16}$ FATS data provide the share of foreign affiliates' value added in the total business economy. This share has been multiplied by the share of the business economy in the total economy according to the national accounts, thereby (for example) assuming that the government is not foreign controlled.

${ }^{17}$ In 2015 , the corresponding share was $44 \%$.
} 
(30\%), Slovakia (30\%), Romania (29\%) and Estonia (29\%), for which intra-EU relations play the dominant role.

On the lower end of the scale, we find mostly southern European countries, but also France, Denmark and Finland. The EU28 average is 14\%, nearly half of which controlled by countries outside the EU.

Figure 3 breaks down the intra-EU shares given above into the shares of the most relevant countries in this context. German companies play an important role in the central and eastern European countries. Estonia has high shares of control by Finland and Sweden.

Figure 3: Share of total economy value added created by intra-EU controlled enterprises, by country of foreign control, 2014

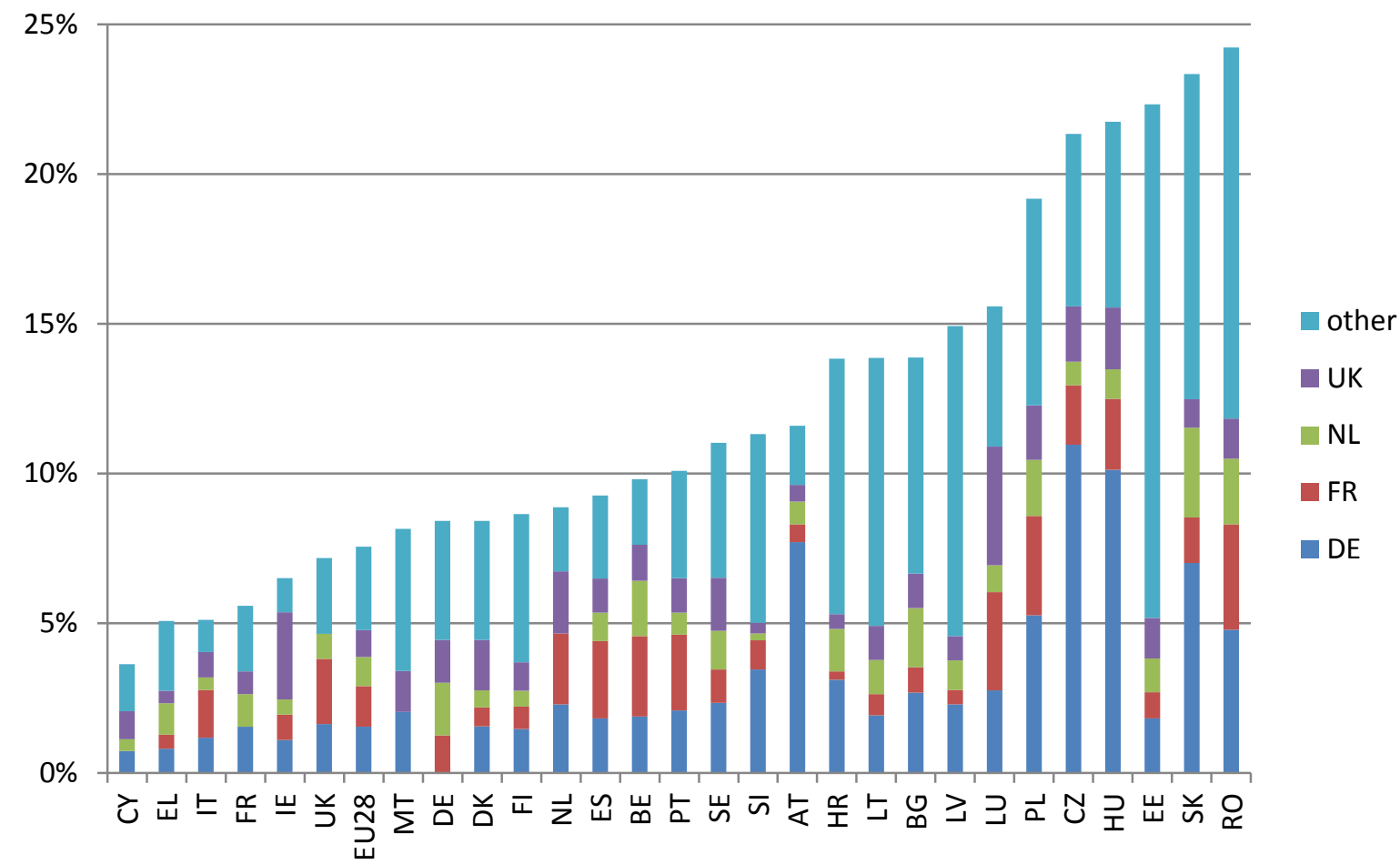

Figure 4 breaks down the extra-EU shares given in figure 2 into the shares of the US and other countries. In Ireland, nearly $90 \%$ of extra-EU controlled value added is created by UScontrolled companies. In the EU as a whole, US units generate around $50 \%$ of all value added of extra-EU-controlled enterprises. 
Figure 4: Share of total economy value added created by extra-EU28 controlled enterprises, by country of foreign control, 2014

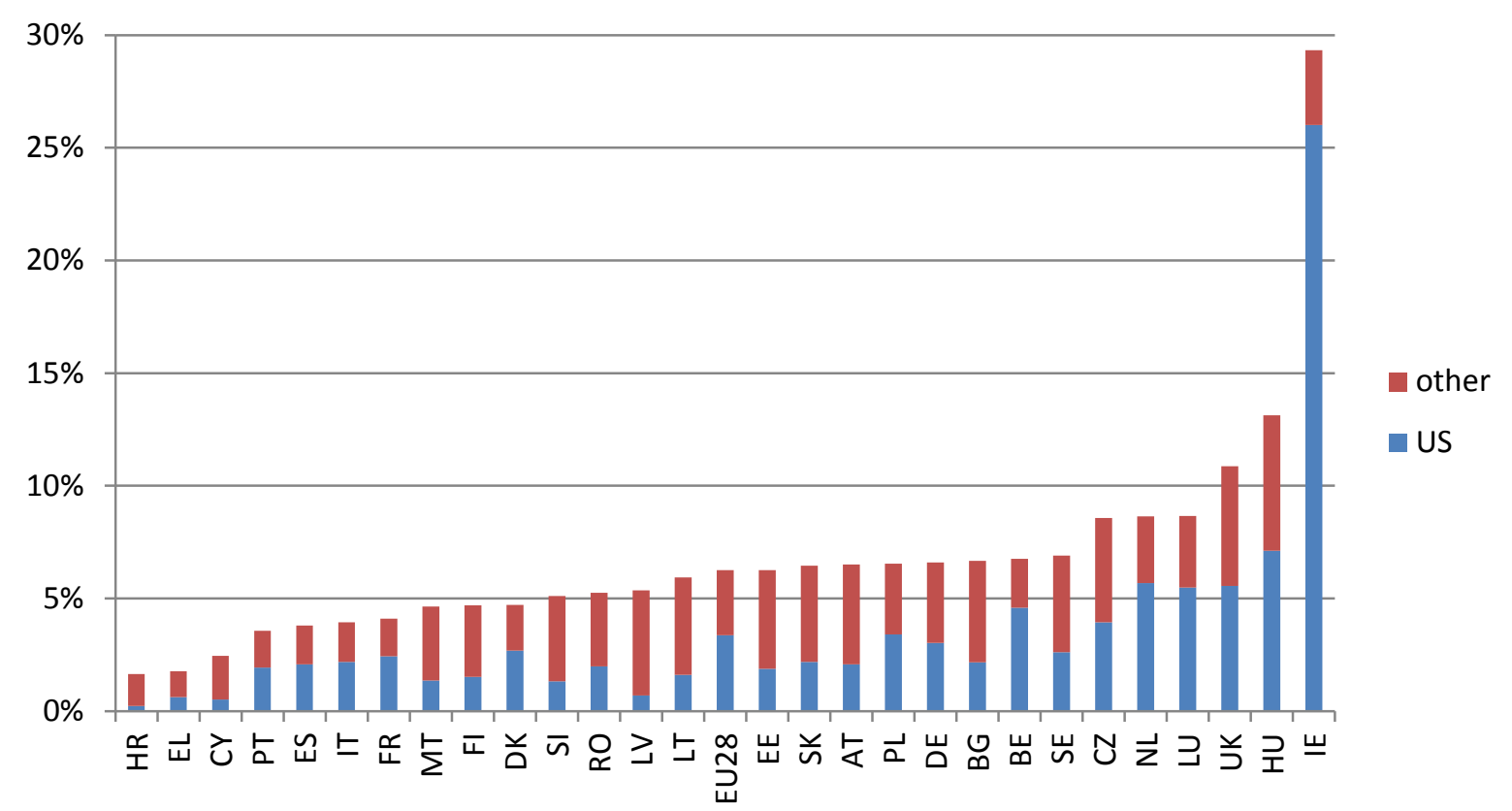

Whereas the share of US-controlled production in Ireland is very high compared to other countries, the level of value added (in euro) in this country is modest compared to some of the bigger countries of the EU. Figure 5 shows in which countries non-EU controlled enterprises create the most value added. It shows that $26 \%$ of the total value added creation in the EU by extra-EU controlled enterprises takes place in the UK and $21 \%$ in Germany.

Figure 5: Share of total EU28 value added created by extra-EU28 controlled enterprises in $\mathrm{EU}$ countries, 2014

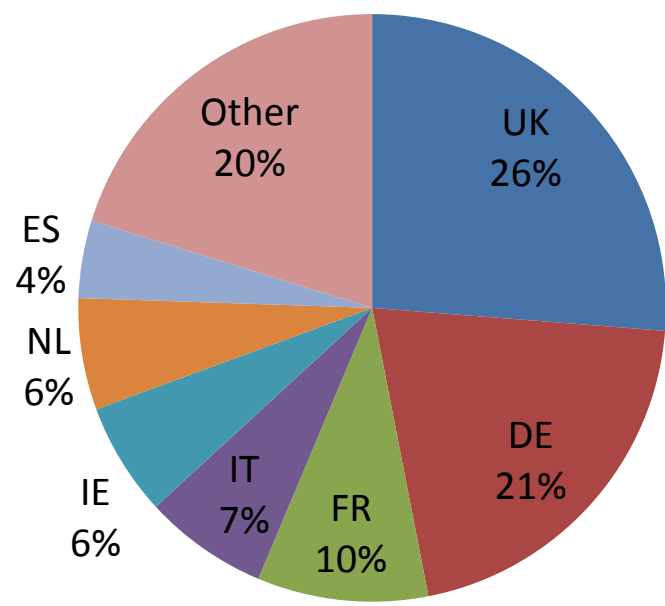


As a second example, we have asked the question the opposite way around - how about EU enterprises having affiliates outside the EU and what do they control? Unfortunately, outward FATS statistics do not provide data on value added. Instead, we will use employment data. According to the FATS statistics, in 2014, foreign affiliates of EU enterprises employed around 14.4 million persons outside the EU (for comparison: the total number of employees in the EU was about 135.5 million). Figure 6 shows that France has the highest share $(25 \%)$ in that number. France, the UK and Germany together are responsible for nearly two thirds.

Figure 6: Share of total employment in extra-EU affiliates of EU enterprises, by country, 2014

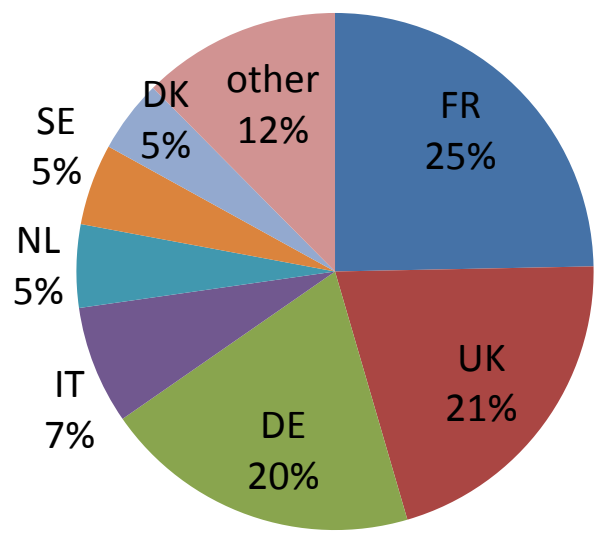

Figure 7 shows in which continents the employees of these affiliates of EU enterprises were working. The largest share of employees is in (North, Central and South) America, half of which is in the US.

Figure 7: Share of total employment in extra-EU affiliates of EU enterprises, by continent, 2014

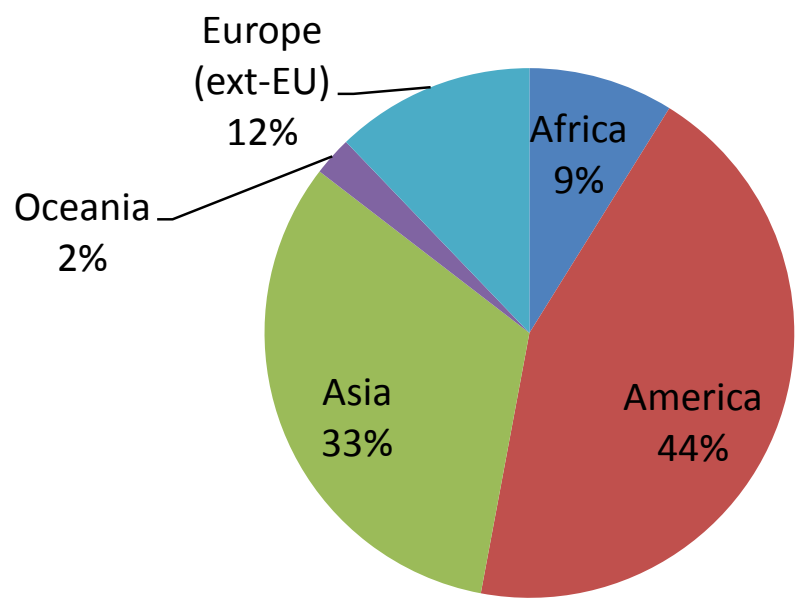


The inward FATS statistics also provide insight in foreign controlled employment in the EU. The shares of foreign controlled employment can be quite different in some cases from the shares of foreign controlled value added that were presented above. Figure 8 plots these shares against each other, in relation to the EU28 averages for each indicator ${ }^{18}$. It gives a picture of the different exposure to globalisation experienced in different countries.

Figure 8: Foreign controlled value added shares versus foreign controlled employment shares, 2014

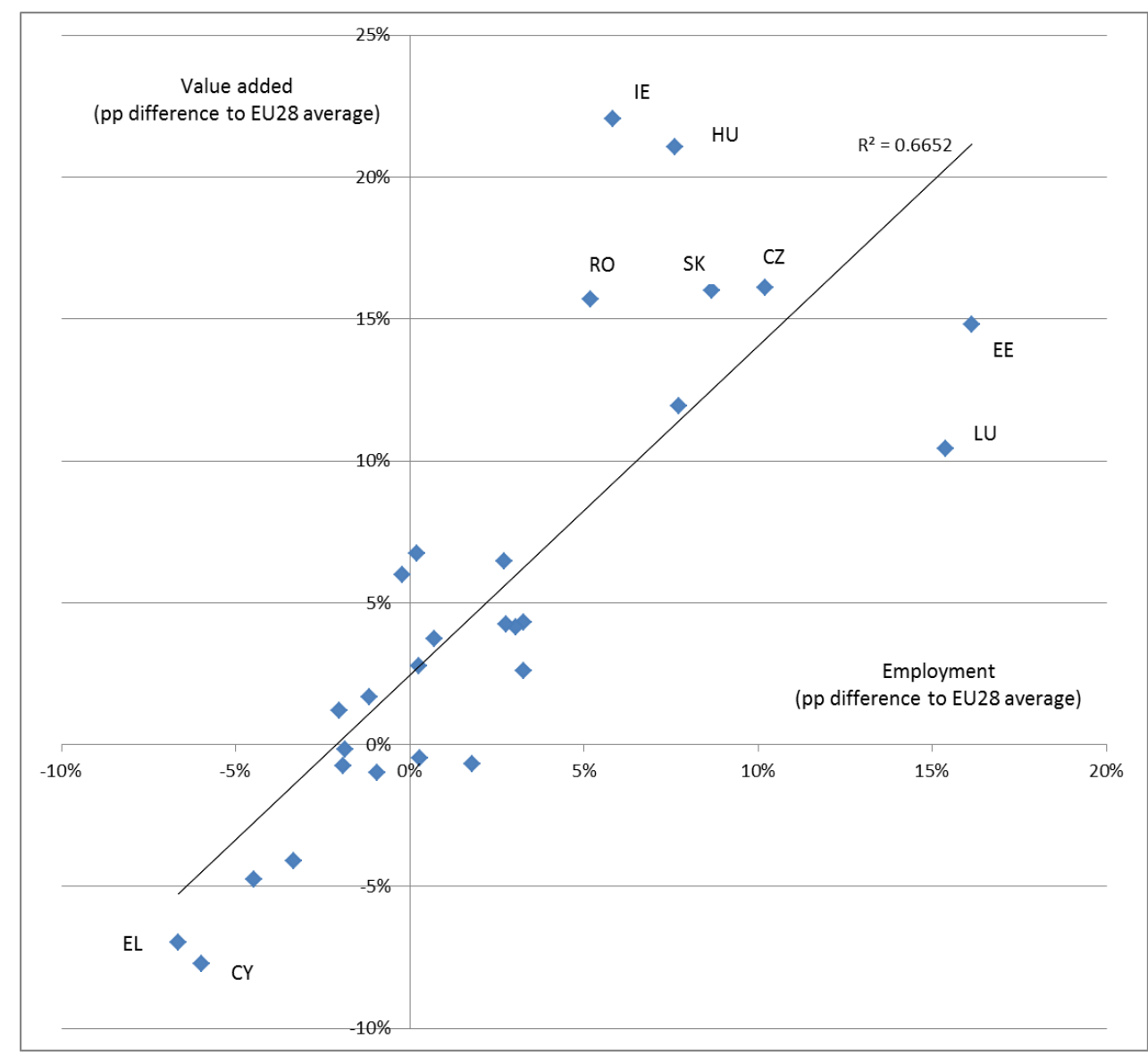

While there is an (expected) correlation between the two indicators, there are some interesting outliers. For example Ireland and Hungary score much less high on employment than on value added, while the opposite is true for Estonia and Luxembourg. Romania, Slovakia and Czech Republic are also more exposed to foreign control of value added than of employment. It should, therefore, not come as a surprise if future globalisation events involving relocations out of the countries would affect those countries mentioned much more than others in terms of shocks to local production and employment.

Greece and Cyprus are the countries that are currently least exposed to foreign control, on both dimensions. This is interesting in the case of Cyprus, since it is well known that many non-Cypriot enterprises maintain special purpose entities there, however these do not generate significant additions to either employment or value added.

\footnotetext{
${ }^{18}$ For the employment data, we used the same grossing-up technique to national accounts as outlined in footnote 16 for value added.
} 


\section{A new initiative in European national accounts}

Building on the profiling work described in section 3 above, a new EU pilot project has started in 2018 to assess the treatment of a small number of (profiled) MNEs in the national accounts of the countries concerned. The initial focus will be on the allocation of value added for these companies across countries. The selection of companies is based, among other criteria, on significance for GNI at national level.

The primary reason behind this is the administrative use of GNI as base of the biggest socalled "own resources" of the EU budget. However, it has also utmost importance for piloting how the exhaustiveness and consistency of the National Accounts and Balance of payments aggregates across Europe can be ensured in the future under conditions of globalisation. The allocation of R\&D by country will play an important role in this exercise.

The time horizon of this piloting exercise is until 2019, which coincides with the next NA benchmark revision in most EU Member States. If the pilot is successful, it may provide a blueprint for a systematic, consistent and exhaustive approach to the recording of MNEs in national accounts and balance of payments in the future.

The full fruits of a possible new approach involving systematic cross-country collaboration of statistical compilers will, however, most likely stretch until the following common benchmark revision in all EU Member States, agreed for 2024. 